H. H. DHANJEE, I. BUSLOV, I. W. WINDSOR, R. T, RAINES, B. L. PENTELUTE*

S. L. BUCHWALD* (MASSACHUSETTS INSTITUTE OF TECHNOLOGY, CAMBRIDGE, USA)

Palladium-Protein Oxidative Addition Complexes by Amine-Selective Acylation

J. Am. Chem. Soc. 2020, 142, 21237-21242, DOI: 10.1021/jacs.0c09180.

\title{
Lysine-Selective Oxidative Addition Complexes for the Conjugation of Proteins, Antibodies, and Peptides
}

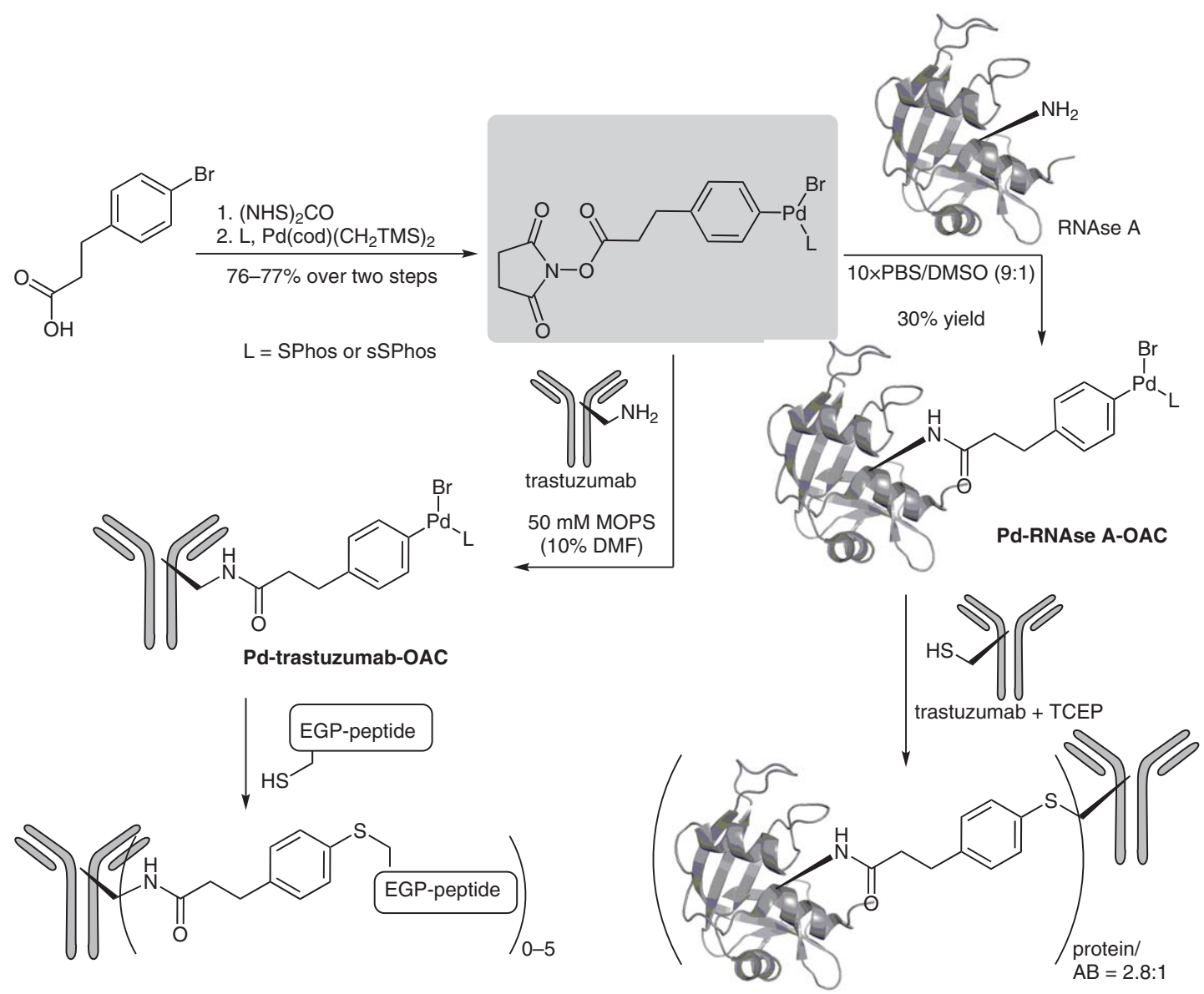

Significance: Many protein conjugation strategies require the pre-installation of aryl halides onto the protein or are selective for cysteine side chains. The authors describe stable NHS ester based PdOxidative Addition (OA) transfer reagents that can be used for the amine-selective conjugation of proteins, peptides, or antibodies. The strategy described was further used for the protein-protein cross-coupling of lysozyme $\mathrm{C}$ to anthrax protective mutant antigen K563C.
Comment: The bifunctional OAC transfer reagent was developed by the installation of an NHS ester on one end and a biaryl phosphine supported PdOAC on the other end. The NHS ester is capable of selectively acylating amine side chains of proteins installing a Pd-OAC reagent on the surface of a protein or antibody. The resulting Pd-OAC complexes undergo efficient conjugation with thiol-containing substrates such as proteins, peptides, and antibodies. Protein homodimerization was achieved with dithiol linkers.

\section{NHS esters}

oxidative addition complexes

lysine-selective bioconjugation 